\title{
Preceptorship: an analysis within the phenomenological perspective*
}

\author{
Preceptoria: um olhar sob a ótica fenomenológica
}

Preceptoria: una mirada bajo la óptica fenomenológica

\section{Gilberto Tadeu Reis da Silva ${ }^{1}$, Vitória Helena Cunha Espósito², Dulce Maria Nunes $^{3}$}

\begin{abstract}
Objective: This study aimed to understand and interpret the meanings of preceptorship, as it shows itself to the students of an Undergraduate Nursing course. Method: In this study, a qualitative research was used, in the phenomenological modality. Eight students undergoing preceptorships were interviewed, the subjects of this study, with the guiding question: "What is a preceptorship for you?" Results: After the analysis of the descriptions, the following thematic categories emerged: approximation, coexistence, education and orientation. Conclusions: Preceptorship was shown to be an educative action, referring to a situationality that unfolds in three dimensions: personal, citizenship and professional. From this construction, always unfinished, it was necessary to reflect about the education of the nurse.
\end{abstract}

Keywords: Preceptorship; Nursing education; Nursing research

\section{RESUMO}

Objetivo: Este estudo teve como objetivos compreender e interpretar os sentidos do fazer preceptoria, tal como ela se mostra para os alunos de um Curso de Graduação em Enfermagem. Métodos: Nessa busca utilizamo-nos da pesquisa de natureza qualitativa, modalidade fenomenológica. Foram realizadas entrevistas com oito preceptorandos, sujeitos deste estudo, a partir da pergunta norteadora: "O que é preceptoria para você?”. Resultados: Após a análise das descrições, emergiram as seguintes categorias temáticas: aproximação, coexistência, formação e orientação. Conclusões: A preceptoria mostrou-se como ação educativa que remete a uma situacionalidade que se desdobra na tridimensionalidade pessoal, cidadã e profissional. A partir dessa construção, sempre inacabada, necessário se fez refletir sobre a formação do enfermeiro.

Descritores: Tutoria; Educação em enfermagem; Pesquisa em enfermagem

\section{RESUMEN}

Objetivo: En este estudio se tuvo como objetivo comprender e interpretar el sentido de hacer preceptoria, tal como se muestra a los alumnos de un curso de Pregrado en Enfermería. Métodos: En esa búsqueda utilizamos la investigación de naturaleza cualitativa, modalidad fenomenológica. Se llevaron a cabo entrevistas con ocho preceptorandos, sujetos de este estudio, a partir de la pregunta orientadora: “Qué es preceptoria para ti?”. Resultados: Después del análisis de las descripciones, emergieron las siguientes categorías temáticas: aproximación, coexistencia, formación y orientación. Conclusiones: La preceptoria se mostró como acción educativa que remite a una situación que se desdobla en la tridimensionalidad personal, ciudadana y profesional. A partir de esa construcción, siempre inacabada, se hace necesario reflexionar sobre la formación del enfermero.

Descriptotres: Tutoria, Educación en enfermería; Investigación en enfermería

\footnotetext{
${ }^{*}$ Extracted from a chapter of the Doctoral Dissertation: Preceptoria como Ação Educativa: uma leitura hermenêutica fenomenológica (Preceptorship as an Educative Action: a phenomenological hermeneneutic analysis). São Paulo (SP): Universidade Federal de São Paulo; 2003.

${ }^{1}$ Ph.D, Full Professor at Faculdade Santa Marcelina, Leader of Núcleo de Ensino, Pesquisa e Extensão em Formação e Educação em Saúde (NEPEFES)

- FASM - São Paulo (SP), Brazil.

${ }^{2}$ Ph.D, Full Professor at Faculdade de Educação da Pontifícia Universidade Católica de São Paulo - PUC-SP - São Paulo (SP), Brazil.

${ }^{3}$ Ph.D, Associate Professor at the Maternal-Infant Nursing Department of Escola de Enfermagem at Universidade Federal do Rio Grande do Sul-UFRGS

- Porto Alegre (RS), Brazil.
} 


\section{INTRODUCTION}

In a society that is more and more individualistic, like the one we live in, the speed at which ethical and moral values have crumbled is perplexing - traditional values that, either visibly or not, have guided life, education and the behavior of people in society.

Modernity, marked by the pinnacle of scientific knowledge, dictates ways of knowing and being in the world, in which measuring, precision and objectivity are well-regarded; human subjectivity ends up being eliminated from the scientific process of knowledge construction. Both the healthcare and the educational areas cover complex issues, working with Man in his social relations, not always viewed through the traditional logic of thinking, which looks at Man in other perspectives ${ }^{(1)}$.

Since we inhabit the world of education, we developed the present study at Faculdade Santa Marcelina, located in the eastern region of greater São Paulo. This institution is guided by a code of ethics that reflects Luigi Biraghi's* thoughts ${ }^{(2)}$.

By living with undergraduate students, particularly in the nursing area, in the act of educating, our observations were focused on preceptorships as a possibility in the education of the nurse.

In the present study, it is understood that preceptorship is an institutional academic support program for undergraduate students in the Nursing course. As such, it is inserted in the scope of education. The students with whom we coexist in the school environment, in the classroom or wherever, are reflective beings, concerned with their singularity as persons, with the ways of responding to life and with their own bodies. At the same time, they are singular Beings, they are Beings-with, that is, with people and with things. They are temporal beings, concerned about themselves, but also aware of themselves and projected for the future ${ }^{(3)}$.

The person performing preceptorship activities is in the school, i.e., is found in the educational sphere. By the expression "being in the school", we are faced with two possibilities: simply being there or existing in the presence, being part of the educational work ${ }^{(4)}$.

Therefore, in our daily work, by living with preceptorship, which involves preceptors and students, some questions arose, linked to this teaching strategy.

We verified that the research studies about preceptorship were concerned with approaching the theme as a characteristic teaching, especially in courses from the healthcare area, where preceptorship teaching happens by pairing teachers and students, however, without explicitly stating the principles and fundamentals that guide

\footnotetext{
* Religious figure, doctor of the Ambrosian Library, founder of Congregação das Irmãs de Santa Marcelina.
}

this work.

We observed that there were changes in both the way of executing the preceptorship and the way of coordinating it since, when preceptorship activities are developed, evaluations are performed systematically to contribute to the organization of this work, permitting its reordering and realignment as processes ${ }^{(5)}$.

Thus, we planned the present study with the proposal of unveiling some of the facets of how preceptorship is perceived by nursing students in the aforementioned institution.

From the discourse of the preceptorship students, we tried to find the essence of how the preceptorship shows itself to them, and thus understand the senses and perform the reading of the meanings they attribute to preceptorship.

\section{METHODS}

In this course, in a phenomenological perspective**, teaching and learning consist in the possibility people have of becoming aware of the need to reorganize a personal and social project.

We believe that this enables a professional attitude to be more open to reality, more stimulating, leading the student and the educator to reflect about their "being", their "doing" and their "acting", towards a reflective and active thinking about the professional practice according to a phenomenological perspective. It is fundamental to have in mind that education happens in a dialectical relation, since it is a relation of care and zeal between the educator and the student. It is, therefore, an open relation towards a synthesis that is not enclosed in itself, but which remains as a horizon of possibilities ${ }^{(4)}$. We observed that, differently from quantitative research, there is no pre-given objective in this form of research; this is supported by the interrogation, making its way as it goes along.

\section{Basic ideas of phenomenology}

Phenomenology is the study of essences ${ }^{(6)}$. It came and grew, having its origins in Husserl's thoughts. Its fundamental point lies in the description, as a way of going to things themselves, and this means focusing, situating whatever needs to be known and, by situating, we start to describe it and aim for comprehension. This comprehension is only possible when the researcher, using the resource of phenomenology, assumes the result of the reduction as a group of assertions that are significant

** Phenomenology: Word that has its origins in the Greek term phainomenon, which means that which appears; that which shows itself; what is clear to vision. Phainomenonis is the Greek expression, derived from the verb phainestai, which means showing oneself. Phainomena refers to what is shown in itself, in broad daylight. 
for the researcher himself, but point to the subject's experience, i.e. to the subject's conscience of the phenomenon. This group of assertions is named units of meaning, which should be taken exactly as the subject describing the phenomenon proposes them. Afterwards, the researcher transforms the subject's everyday expressions in expressions that are proper of the statements that support whatever is being sought. Finally, the researcher organizes a synthesis of the units of meaning. This synthesis is a result of the analysis of the many subjects of the research ${ }^{(4)}$.

With this intention, we chose this course and, for a first approach - the highest comprehension of preceptorship - we "asked how this experience shows itself to those who experience it". Considering the students as partners in this ongoing construction, we interviewed, first, nursing students, using the following guiding question: "What does 'preceptorship' mean to you?"

The guiding question ${ }^{(7)}$ of the phenomenological interview, when formulated, entails difficulties, because it detects truths that are not absolute, since there are many possibilities for the phenomenon to show itself. There will always be facets of the phenomenon that need to be unveiled. There will always be something to be learned; the phenomenon does not exhaust itself; it is revealed in perspectives and profiles.

We know that the phenomenological method seeks reduction - more specifically, it seeks to obtain access to the thing itself, like what happens in the pre-reflective phase, in the experience of the subjects. Therefore, we collected the students' phenomenological descriptions, the subjects of this research. The subjects were contacted twice previously, so as to become familiar with each other and enhance the approximation ${ }^{(8)}$. In this research route, we listened to the students, subjects of this study, recording each description and probing the symbolic universes*** present in their discourse and through which they manifested their own comprehension about themselves, about the other, the world and the preceptorship ${ }^{(7)}$.

In the phenomenological research, when the theme is delimited and the guiding question is proposed, the researcher will interrogate according to whatever disquiets him, which is his inquiring region, of philosophical nature. The criterion for the number of subjects to be interviewed is guided by the saturation of established data. In this study, during the data collection process, after the first two interviews, six other descriptions were collected, according to the guiding question. After the units of

*** The symbolic universes are bodies of theoretical tradition that integrate areas of meanings and cover the institutional order in a symbolic totality, providing conditions by making these legitimate, so that the unifying integration of separate institutional processes can happen. meaning highlighted in the phenomenological reduction were read and extracted, the thematic confluences were organized, and the common themes were detected, as well as divergences and idiosyncrasies that were present. Next, we observed that the themes emerging from the units of meaning, extracted from the statements, merged towards an organization thus named as open categories, considering that the researcher, as a "being" who attributes meanings, established the ordering. From these themes and the presence of one or more open categories and the idiosyncrasies, a reordering is organized. At this moment, the author can have dialogs with other works, establishing new comprehensions/interpretations of the investigated phenomenon - in this case, the preceptorship.

At this stage, in the come-and-go (part/whole/part) that is characteristic of phenomenological analysis, the researcher presents a synthesis****. It is considered that each comprehension finds an interpretation waiting on its route.

The study respected the ethical-legal aspects of Resolution 196/96 of the National Healthcare Council, being approved by the Review Board of Faculdade Santa Marcelina - FASM - protocol No. 004/02, and by the respective Review Board of Universidade Federal de São Paulo - protocol No. 0315/03. Before the interviews were started, the term of consent was fully read, requesting agreement with this research and signature of the document by those who agreed to participate in the interview.

\section{CONSTRUCTION OF THE RESULTS}

By retaking the history of our professional and academic pathway, from the experienced world, we considered that, by analyzing and experiencing preocuppations, challenges, difficulties, renunciations and superficialities, we reviewed these routes, causing the necessary distancing so that new comprehensions and interpretations could generate interrogations in this movement. These interrogations, when constituted, were arranged so that we could see ourselves, constitute ourselves as teaching beings, preceptors and advisors, building our own humanization along this route.

As teachers, we asked ourselves: How can the professor mediate the students' knowledge and their learning in the constitution of their professional background? How do we see ourselves?

\footnotetext{
**** Synthesis does not mean here a union or grouped linking of representations; but as "syn", which means allowing something to be seen in its group as something. It has the function of "as", since they allow something to be seen "as" something. Therefore, phenomenology, as phainestai and logos, means allowing things to manifest as they are, without projecting our own categories upon them.
} 
We see ourselves, then, as professors, preceptors, when having dialogues with our students about their and our experiences. In this exercise, when what is reported and what is learned are put in practice and shared with the student, an educative situation is outlined. Teaching and learning merge with each other in existence.

Therefore, the professor, in the experience of preceptorship, is understood as a being who is a teacher/ preceptor/educator, an ontic/ontologic being, who, "being" in the concreteness of the educative action, is willing to intervene and transform. "Trans-form-ation", which, at FASM, with humanization as its guide, is directed by christocentric, universal values.

The preceptorship process, in the perspective focused on, seeing man and world as a whole, is far from being simply a process of teaching and learning, or even being a merely specialized technical preparation. This holistic and fluid view is what permits searching the phenomenon in bases that are more solid, so that it will be possible to invest in the construction of a solid professional education with ethical bases.

\section{Preceptorship as an institutional project: the mission of FASM and its challenges}

When talking aboutthe mission of FASM in terms of challenges, and for what is presented to us, it should be observed that this part is inserted in a larger group, which aims to make the mission of the institution possible and put it in practice. With this intention, two challenges are presented: providing university education in a place where the tone is the social exclusion of its elements, which reveals the concreteness of the institutional presence in the socioeconomic context where people live, and which seems to be the moving force for the consolidation of actions. The second, the daily construction of a politicalpedagogical process that allows the student to go beyond merely doing, allowing the professor to act intellectually, contributing with theoretical, technical, and especially practical teachings, committed to the transformation of society through time. In this movement, the interventions seek and have also caused politically necessary changes, by transforming the subjects involved in the process into agents. For that to happen, we still consider, poetically, that the ideal, the possible, is not ready: it is produced in the situation and built from it. Often, it is hidden "within the shell of the impossible". To "discover" it and "activate" it, it is necessary to resort to utopian imagination, which is articulated with reason, and which pushes the desire that is unveiled as the fruit. Building the possible means to explore faraway limits to reduce them and erect bridges, bring margins closer together, constructing places, scrutinizing the alternatives of action in order to improve them, always.

About the research itself:

With the challenge proposed, the concerns about how to do, the Preceptorship Program was instituted as an institutional program. But what is preceptorship?

Preceptorship is seen as an institutional academic support program for undergraduate students of the Nursing course. It has usually been approached as a characteristic form of teaching, especially in the healthcare courses, where teaching comes from their peers, professors-students, without the explicit statement of principles and fundamentals that govern this work. This concern made us investigate it, at first, as it is organized a teaching strategy. Later, in the study mentioned herein, under an educational phenomenological perspective, preceptorship is investigated according to how it happens when experienced by the students, before critical-reflexive categories can direct or commend interpretations that are strange to the process. And what does preceptorship mean for the preceptor?

According to their experiences in the development of preceptoral activities, we observed that these are distinct, peculiar and surprising when, in their active participation in monthly encounters, in everyday dialogs at the college, courses, or even when they verify the academic results, they create bonds and generate "encounters". What is observed is that the process of preceptoring, according to the perspective in focus, is far from being simply a process of teaching and learning, or even corresponds to a merely technical, specialized preparation. The parties involved are requested to take a stand in view of an educational conception as given in the situation, in existence, seeing man and world as a whole. This holistic view is what permits seeking the phenomenon in more solid bases, in order to invest in the construction of coherent and ethically based professional education.In this course, in a phenomenological perspective, teaching and learning consist in the possibility that the human being has of becoming aware of the need to see himself inserted in the human world, a being with the other and, then, reorganizing a life project that is both personal and social. We believe that this elicits a professional attitude that is more open to reality, more stimulating, leading the student and the educator to reflect about their "being", their "doing" and their "acting", towards a reflexive and active thinking about the praxis, in an existential perspective. In this perspective, the educational action, developed with contributions from the Philosophy of Existence, characterizes a course of experiences, and may even become an effective space of education, exposition and production of knowledge and information that are necessary for the education of both, professor/preceptor and student, to be performed in everyday life and contact. 
Furthermore, since the proposed work has a practicaltheoretical nature, being thus governed by ethics made explicit in the institutional ideality, the how-to-do finds in preceptorship, as an institutional project directed to the professional education of the nurse, not only a technique or teaching strategy, but a way to seek trans/form/ation. Producing a trans/form/ation means producing an other, substantially different from the earlier, a trans-making.

By exposing the practical-poetical nature, creator of what is intended, we seek the essence of the preceptorship phenomenon. We are placed as hermeneuticians, listening to the students and, from their phenomenological discourse, we approach their way of apprehending it, like what happens in their pre-reflexive, reply rooted in their lifeworld, in the time and space of each of them, happening in situation and movement. Having the collected statements available (phenomenological interviews from eight students), after analysis and interpretation, four thematic categories were selected: approximation, orientation, education and coexistence, themes that are unveiled as essential for the preceptorship process.

Significantly, about approximation, preceptorship, by providing the approximation of the students with the professors in everyday living, this requests that they reevaluate their values, searching for common points so that the other can be accepted and, as such, be able to start this proposal. They suggest that there should be an encounter of horizons, those of the student and those of the teacher, so that another form of seeing the world could be established. This understanding is revealed, according to the expressions of some students, as the fact that approximation, beyond the academia, affects their personal and social life, with commitment and intentionality of those involved being important and necessary. Another point seen as fundamental to preceptorship is its orienting characteristic.

We should remember that, when the meanings attributed to orientation are reevaluated, they have christocentric values as their reference (2), whose ethics encourages an action, a concrete intervention, guaranteeing that this orientation will go along the changing times. By having the teacher as a reference, the students seek him to clarify doubts and is sure that the professor is willing to listen to them at any time. Orientation for this subject is understood as the promotion of the good things that the student has, and as stimulation, encouraging him to grow socially, intellectually and institutionally as a person in the university environment. In this study, orientation means perceiving the inclination of a person or student, encouraging him toward his goals. It also suggests actions aiming at guiding, encouraging and stimulating.

In the significant extreme and that is not privileged in different statements, it is stated that speaking about orientation presupposes also speaking about disorientation, an antagonistic meaning registered lexically as misleading, misguiding, disorienting as a human possibility of "being with the other" in the being's inappropriateness. The student manifests that having the professor as a reference makes it possible for the student to guide himself in a direction that orients him on "how to position himself" in the face of the different possibilities of choice.

The students interviewed perceive the professor as the one who guides them, showing the direction, influencing them. An articulator that apprehends the potentials, stimulating and encouraging them in their pathways, thus allowing them to, when managing their doubts, be able to restart their search for bearings, even if they are far off the track. The importance of orientation is highlighted when, by orienting, the master presents possibilities, images, diagrams of reality, not always realized by the student, and which can favor the formation of a professional identity committed with the other.

Of the thematic education we say: By shaping our actions, (form + action), we are concerned with keeping them coherent with the principles and values that are fundamental for the institutional mission. By making them feasible, we kept ourselves faithful to a group of ethics whose foundation has had, as its horizon, the evangelic method***** since the beginning of the $19^{\text {th }}$ century. It says: "Youth is perspicacious, sharp-spirited and finely sensitive to unveil the most subtle feelings of the activities, both healthy and banal, incrusted in the imperceptible core of a life". The Marceline educator is the one who adapts to the life of the students, being with them in every moment, always around them, education through concrete actions more than with words.

The statements emphasize the students' belief that all questions and doubts should be clarified before their graduation. Therefore, we see that their perception of education is exposed as something that is limited to a four-year period.

However, we bring another dimension, when a new perspective of "education" emerges as the result of a process of becoming, something that is born from an internal process of constitution which remains in continuous evolution and improvement. This comprehension of the term education is what makes the establishment of an "educational goal" something that one should be wary of, an action foreign to the process itself, because it will always be secondary to the process. On the other hand, it reaffirms that, in education, everything is preserved, nothing ever disappears. It is not about acquiring something qualitatively new, or from ${ }^{(5)}$ what is taught about this or that, but about seeking some sort of knowledge about oneself, experienced and

***** Biraghi L. Positio super virtutibus. Rome: [s.n.]; 1995. 1v. 
directed to something that is not educational.

Coexistence also emerges from the thematic research, bringing as its broader sense, being in the world with the other as proper of the human condition, aiming to understand this way of being with the other. We observed, significantly, that when the subjects manifest themselves in the research, they believe that their academic life brings them closer to their professional and docent work, as a being in the world. At the moment when that occurs, we have the liberating, authentic knowledge, not merely the reproduction of knowledge. By welcoming the student, the docent will possibly express that the active attitude of the professor is recognized as its own, democratic.

Living everyday with the presence of the professor, the student builds an approximation - a bridge - between worlds. It is with the reality of the outer world, present in its full variety and diversity existing in the words and actions of the professor and in the experience, that both recognize the difficulties and the steps of autonomy, of liberty and the possible successes become evident. By orienting themselves by the life established in the classroom or in the practical or preceptorship fields, the students, a presence in themselves, engender the construction of their knowledge and that of others as beings-in-the-world.

Beyond the themes focused, a few idiosyncrasies appear in the students' statements that we simply register here: choice, affection and responsibility.

\section{FINAL CONSIDERATIONS}

In the present study, the researchers focus on man in society, as a being with the other, inserted in the world when, by questioning preceptorship in the light of phenomenology, they unveil its essential structures, exposing it as an action of practical-poietical nature. They speak, thus, in this movement, about idealizations, values and diversities. They speak about diversities and situations when, more than happening in a paired relation, it happens in society, in the human world. In this action, being a theoreticalpractical construction, when faced everyday with a way of

\section{REFERENCES}

1. Côrrea AK. A crise do conceito tradicional de homem e suas implicações para a saúde e educação.Santo André(SP): s.n.; 2004. [Conferência proferida no Simpósio de Fenomenologia do Cuidar]

2. Biraghi L. Linhas de ação. Milano: [s.n.]; 1880.

3. Martins J, Bicudo MAV. Estudos sobre existencialismo, fenomenologia e educação. São Paulo(SP): Moraes; 1983.

4. Martins J. Um enfoque fenomenológico do currículo: educação como poíesis. São Paulo: Cortez; 1992.

5. Silva GTR, Alexandre LBSP, Gomes PC. Refletindo sobre a thinking founded on the logic of the improbable, the preceptorship, as an educative action, requires choices and constant decision making in contexts of uncertainty, requesting actions and interventions. In this configuration, the "how" to face institutional challenges is changed: It is not merely restricted to an academic program, but it goes on to demand the view of insertion of subjects in the world, in educational situations, when the contribution of the research, allied to the conscience of the political role, either visibly or not, limits the guidelines that outline the actions proposed as educational. Therefore, it is necessary to count on the aid of ethical philosophy, as a phenomenological thought, but also hermeneutic, illuminating the construction of the responses to the challenges made to the conclusion of the institutional mission. In this sense, we think that we are exposing a conception that, anchored in the biraghian thinking, illuminating the doing in the action, in society and the world, responds coherently to the proposed challenges made by the institutional mission. In this movement, what is exposed beyond the preceptorship is the Marceline conception of education itself.

Concluding, it is important to highlight that phenomenology educates us for continuous dissatisfaction with the conclusions reached, the unending search for truths, knowing beforehand that there is always more to obtain and to speak of, retaking comprehension at each instant and never considering itself finished.

The questioning puts us in an attitude of opening to what is shown. Therefore, the phenomenon is always seen within a context.

It is still necessary to mention that our education in the healthcare area makes it difficult to tread some type of knowledge that has not been thoroughly studied, although the scientific production in this area, has been treading a pathway of appropriation of the philosophical thinking, aiming at better understanding the human being, subject of its actions of caring, and imprinting, with increasing strictness, the basic philosophical assumptions of phenomenology and hermeneutics, which also shows the continuity in their studies.
Preceptoria em Enfermagem, rumo para o Desenvolvimento do Ser Humano [resumo]. In: $53^{\circ}$ Congresso Brasileiro de Enfermagem, 2001, Curitiba(PR). Curitiba; 2001.

6. Husserl E. A filosofia como ciência do rigor. Tradução de Albim Blau. Coimbra: Atlântida; 1965.

7. Espósito VHC. A escola: um enfoque fenomenológico. São Paulo: Editora Escuta; 1993.

8. Simões SMF, Souza IEO. Um caminhar na aproximação da entrevista fenomenológica. Rev Latinoam Enferm. 1997; 5(3):13-7. 